\title{
$N A G 5-814$
}

Age Constraints for the Present Fault Configuration in the Imperial Valley, California: Evidence for Northwestward Propagation of the Gulf of California Rift System

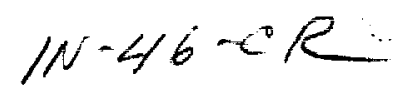

\author{
Shawn Larsen \\ Seismological Laboratory \\ California Institute of Technology; Pasadena, CA 91125 \\ Robert Reilinger \\ Earth Resources Laboratory \\ Massachusetts Institute of Technology; Cambridge, MA 02139
}

\begin{abstract}
Releveling and other geophysical data for the Imperial Valley of southern California suggest the northern section of the Imperial-Brawley fault system, which includes the Mesquite Basin and Brawley Seismic Zone, is much younger than the 4 to 5 million year age of the valley itself. A minimum age of 3000 years is calculated for the northern segment of the Imperial fault from correlations between surface topography and geodetically observed seismic/interseismic vertical movements. Calculation of a maximum age of 80,000 years is based upon displacements in the crystalline basement along the Imperial fault, inferred from seismic refraction surveys. This young age supports recent interpretations of heat flow measurements, which also suggest that the current patterns of seismicity and faults in the Imperial Valley are not long lived. The current fault geometry and basement morphology suggest northwestward growth of the Imperial fault and migration of the Brawley Seismic Zone. We suggest this migration is a manifestation of the propagation of the Gulf of California rift system into the North American continent.
\end{abstract}

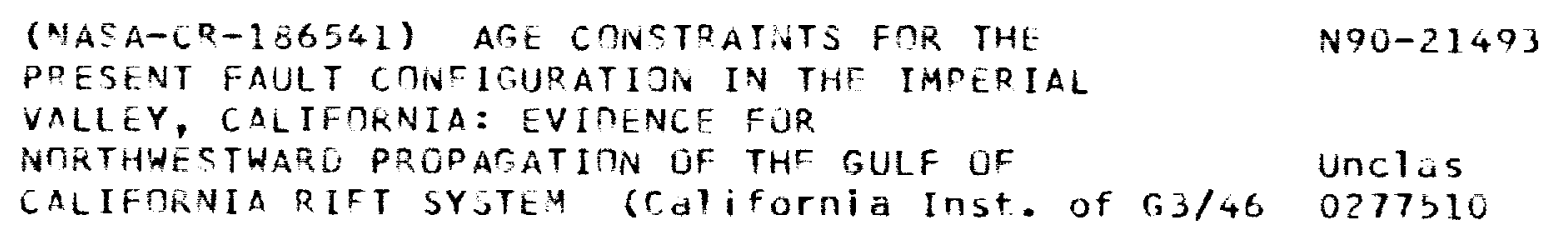




\section{Introduction}

The Salton Trough is a complex transition zone between crustal spreading in the Gulf of California and right-lateral transform motion along the San Andreas fault system (Figure 1). The Imperial Valley is that section of the Salton Trough north of the U.S. - Mexico border and south of the Salton Sea (Figure 2). The Trough is characterized by predominately right-stepping, right-lateral en echelon faults, presumably linked by zones of crustal extension [Lomnitz et al., 1970; Elders et al., 1972]. It is a 150 by $300 \mathrm{~km}$ structural depression, 4 to 5 million years old, and filled by up to $15 \mathrm{~km}$ of late Cenozoic sediments. The seismic velocity of the lower $5-10 \mathrm{~km}\left(V_{p}=5.7 \mathrm{~km} / \mathrm{s}\right)$ suggests they are greenschist-facies, metasedimentary rocks [Fuis et al., 1984].

The Imperial Valley and its major fault systems trend northwesterly, nearly parallel to the relative motion between the North American and Pacific plates. Dextral faulting predominates, although northeast trending left-lateral structures, as well as dip-slip motion along north-south surface breaks, play a significant role in the regional tectonics [Johnson and Hutton, 1982; Nicholson et al., 1986; Reilinger and Larsen, 1986].

The Mesquite Basin is a subaerial topographic low bounded on the west by the northern Imperial fault and on the east by the Brawley fault (Figure 2). Maximum basin relief is about $10 \mathrm{~m}$ relative to its periphery. Evidence that the Mesquite Basin is actively subsiding includes geodetic measurements of surface deformation and measurements of vertical slip along the Imperial and Brawley faults. We provide evidence that the Mesquite Basin is extremely young compared to the age of the Imperial Valley, suggesting this section of the Imperial-Brawley fault system is at an early stage of tectonic development. We extend this 
hypothesis and suggest ongoing northwestward propagation of the Gulf of California rift system.

\section{Imperial Valley Seismicity and Faulting}

The Imperial Valley is one of the most seismically active regions of California (Figure 3). A significant fraction of this seismicity occurs within the Brawley Seismic Zone, a region of high activity between the northern Imperial and southern San Andreas faults [Johnson, 1979; Johnson and Hill, 1982]. The Imperial fault has ruptured historically, in $1840\left(M_{S}=7.1\right)$ and in $1979\left(M_{L}=6.6\right)$; episodes of creep have been recognized along the fault since 1966 [Allen et al., 1972]. Other major events in the Imperial Valley include the recent 1987 Superstition Hills earthquake sequence: a $M_{S}=6.2$ event produced by slip along a northeast trending seismic lineament, followed 12 hours by a $M_{S}=6.6$ earthquake produced by slip along the Superstition Hills fault [Magistrale et al., 1989; Williams and Magistrale, 1889].

The 1979 surfacial rupture of the Imperial fault extended northwestward 33.1 $\mathrm{km}$ from a point $5 \mathrm{~km}$ north of the border to a point south of Brawley (Figure 4). The predominate strike of the Imperial fault is $\mathrm{N} 37^{\circ} \mathrm{W}$. Along the northwestern most $5 \mathrm{~km}$, however, the fault bends and trends north-south. We refer to this segment as the north extension. Parallel and $6 \mathrm{~km}$ east of the north extension, the Brawley fault ruptured in 1979 along a $13 \mathrm{~km}$ surface break. The rupture pattern generally featured left-stepping en echelon cracks that extended a few millimeters to a few centimeters [Sharp el al., 1982]. A third, yet relatively minor 1 km north-south break named the Rico fault was mapped 6-7 km east of the Brawley fault (Figure 4). The surface breakage along this structure resembled that 
of the Brawley fault zone. The geometrical similarity in strike and separation shown by the north extension, Brawley, and Rico faults, suggest a similar tectonic origin.

The epicenter of the 1940 earthquake was north of the U.S. border, but rightlateral surfacial offsets were larger in Mexico (Figure 3). A maximum surface offset of 6 meters was recorded near the border, with displacement tapering off rapidly to the north [Trifunac and Brune, 1972; Sharp, 1982]. Geodetic measurements indicate 4.5 and $3.0 \mathrm{~m}$ of right lateral slip (coseismic plus postseismic) along the southern and northern halves of the Imperial Fault, respectively (i.e., north and south of the epicenter), with $2.0 \mathrm{~m}$ postseismic slip along a northwest extension of the Brawley fault [Reilinger, 1984]. The 1979 epicenter was south of the border, although surfacial displacement was observed only in the United States. Maximum coseismic surfacial offset was $55-60 \mathrm{~cm}$, with considerable afterslip $(\sim 30 \mathrm{~cm})$ during the following 6 months [Sharp et al., 1982]. Strong ground motion and geodetic modeling [Archuleta, 1984; Hartzell and Heaton, 1983; Reilinger and Larsen, 1286] suggest an average slip of about $1 \mathrm{~m}$ along the fault plane, with small patches of higher displacement (asperities).

The mechanism of strain transfer between the Imperial and San Andreas faults within the Brawley Seismic Zone has been the focus of considerable investigation [e.g., Johnson, 1979]. A conjugate relationship of right-lateral, northwest trending faults perpendicular to left-lateral, northeast trending structures may play a significant role in the regional tectonics [Nicholson et al., 1986]. Although the Imperial and San Andreas faults strike predominately northwest (rightlateral), a left-lateral structure extending northeast from the northern terminus of the Imperial fault is indicated from focal mechanisms and the aftershock pattern 
of the 1979 earthquake [Johnson and Hutton, 1982]. A conjugate fault mechanism is supported by Reilinger and Larsen [1986], who suggested several tectonic models in the Brawley Seismic Zone satisfying geodetically determined measurements of vertical surface displacement. The preferred model consists of a northeast trending left-lateral fault conjugate to a right-lateral northwest trending structure dipping $70^{\circ}$ to the southwest (Figure 3, dashed lines). Neither fault broke the surface but roughly $1 \mathrm{~m}$ slip at depth was required to fit the geodetic measurements. A similar conjugate fault relationship was observed for the 1987 Superstition Hills earthquake sequence [e.g., Magistrale et al., 1989].

Aftershocks from the 1979 earthquake have been relocated following the procedures of Doser and Kanamori [1986] and Klein [1985] (Figure 3). The northeast trending seismic lineament first identified by Johnson and Hutton [1982] is clearly defined. To the north, a tightly constrained group of events following a northwesterly direction is indicated. Epicentral depths for this cluster range from 5 to 11 $\mathrm{km}$, possibly putting them on the $70^{\circ}$ west dipping structure suggested by Reilinger and Larsen [1986]. We have computed focal mechanisms for these events and find them consistent with a northwest-trending right-lateral fault (Figure 3 ). Thus, both seismic and geodetic data suggest the tectonic framework of the Brawley Seismic Zone is marked by en echelon northwest-trending right-lateral faults linked by conjugate left-lateral structures.

Extending southeast from the southern tip of the San Andreas fault is a linear alignment of earthquakes (Figure 3), here referred to as the Sand Hills seismicity lineament. This feature may signify the southeasterly extension of the San Andreas fault, although there is no surfacial geological evidence to support this hypothesis [Sharp, 1882]. 
The earthquake recurrence interval along the Imperial fault is not well constrained. Sykes and Nishenko [1984] use the 39 year interval separating the 1940 and 1979 shocks as well as a 1915 earthquake sequence located near El Centro [Beal, 1915] to estimate a 32 year recurrence rate. Anderson and Bodin [1987] suggest the fault north of the border will next rupture between 2010 and 2050 (50 year recurrence), and the next break along the southern segment to occur between 2170 and 2290 (300 year recurrence). Measurements of surface offset, as well as seismic and geodetically determined estimates of fault slip at depth, indicate the 1940 fault rupture was several times larger than in 1979, in agreement with the larger magnitude for the 1940 event $\left(M_{S}=7.1\right.$ vs. $\left.M_{S}=6.6\right)$. North of the border, however, the magnitude of horizontal surface displacement was relatively constant for the two earthquakes. One explanation is that the fault north of the border may rupture more frequently but with smaller events. Alternatively, the large postseismic slip following the 1840 earthquake indicated by geodetic data, suggests that a significant fraction of strain buildup may be releaved aseismically.

If the entire $49 \mathrm{~mm} / \mathrm{yr}$ movement between the Pacific and North American plates predicted by new global plate models (NWVAL 1) [DeMets et al., 1987] is accommodated across the Imperial fault, 1.0 meter of seismic or aseismic fault slip would require a 20 year interval of strain buildup. More likely, however, a significant component of plate motion is distributed along the Elsinore and San Jacinto fault systems [Sharp, 1981; Pinault and Rockwell, 1984; Snay et al., 1986], as well as faults off the coast of southern California [e.g., Weldon and Humphreys, 1986]. Triangulation and trilateration measurements from 1941 to 1981 in the central Imperial Valley indicate an average displacement across the Imperial fault of $40 \mathrm{~mm} / \mathrm{yr}$ [Snay and Drew, 1988]. Preliminary results utilizing the Global Positioning System (GPS) suggest a similar rate between 1986 and 1988, although 
interpretation of these measurements have been complicated by large displacements from the 1987 Superstition Hills earthquake sequence [Larsen et al., 1988].

Assuming $40 \mathrm{~mm} / \mathrm{yr}$ of plate motion across the Imperial fault, $1.0 \mathrm{~m}$ of potential slip will accumulate in 25 years. This will be equivalent to the earthquake recurrence interval, at least for the northern segment of the Imperial fault, if the $\sim 1.0 \mathrm{~m}$ surface displacement measured in 1940 and 1979 is characteristic of fault displacement and if all slip is generated seismically. Considering the likely-hood of aseismic deformation, as well as the seismic and geodetic models indicating asperities along the 1979 rupture plane, it is reasonable to expect that the average slip generated along the northern Imperial fault during each earthquake (or earthquake cycle) is somewhat greater than $1.0 \mathrm{~m}$. Assuming $2-3 \mathrm{~m}$ of slip (based on the seismic plus postseismic offset estimated for the 1940 earthquake and the maximum slip observed for the 1979 earthquake), more reasonable estimates of earthquake recurrence would be $\mathbf{5 0}$ to $\mathbf{7 5}$ years for this segment of the Imperial fault.

\section{Subsidence of the Mesquite Basin}

First-order leveling surveys crossing the northern Mesquite Basin were conducted by the National Geodetic Survey (NGS) in 1831, 1941, 1974, 1978, and 1980 (Figure 4). Profiles of elevation change from 1931 to 1941,1941 to 1974 , and 1978 to 1980 are shown in Figure 5. The procedure used to determine these crustal movement profiles is described in Brown and Oliver [1976]. Briefly, an estimate of relative elevation change between successive benchmarks is obtained by subtracting the elevation difference between benchmarks measured at some reference time from the difference measured at some later time. These movement profiles have not been connected to any external reference. Therefore, only rela- 
tive movements along the level lines are significant.

The random error for these measurements is comparatively small, less than 1 cm. In addition, elevation-correlated errors (i.e., rod calibration and atmospheric refraction) which can obscure or be mistaken for real tectonic deformation, will not seriously affect the data because of negligible topographic variation along the leveling route (Figure $5 \mathrm{a}$ ).

The 1931-1941 and 1941-1974 profiles have been modeled as coseismic and postseismic deformation from the 1940 Imperial Valley earthquake [Reilinger, 1984]. Displacements for the most recent interval (1978 to 1980) have been modeled as surface deformation from the 1979 earthquake [Reilinger and Larsen, 1986]. The most striking feature of the leveling data is the similar pattern of subsidence across the Mesquite Basin observed on all three profiles, suggesting this deformation style is characteristic for the region. Coseismic subsidence for the 1940 and 1979 events are on the order of $10-15 \mathrm{~cm}$, with an additional $15 \mathrm{~cm}$ following the 1940 earthquake. Total subsidence for the period 1831 to 1980 is about $40 \mathrm{~cm}$.

Elevation along the leveling route is shown in Figure 5a (dashed line). A relatively constant northward slope of -0.0011 radians is observed. This longwavelength trend may mask small scale variations, so we construct a modified topographic profile by removing this regional slope (we add 0.0011 radians to the true profile). The modified profile, or adjusted topography, is shown as the solid line in Figure 5a. The 10-meter depression between 9 and $22 \mathrm{~km}$ marks the boundary and surface relief along the northern part of the Mesquite Basin. The topographic relief is well correlated with the seismically generated subsidence, strongly suggesting the Mesquite Basin formed by many episodes of seismic activity similar 
to the 1940 and 1979 events.

Vertical surface slip along the northern section of the 1879 rupture plane ranged from 0 to $30 \mathrm{~cm}$ (including 6 months afterslip), while vertical offset along the Brawley fault was 0 to $24 \mathrm{~cm}$ [Sharp et al., 1982]. Measurements of vertical slip following the 1840 earthquake were sparse, although the sense of displacement was generally the same as in 1979 [Sharp, 1982]. During an earthquake swarm in 1975 , up to $20 \mathrm{~cm}$ of vertical displacement was observed along the Brawley fault and an additional $20 \mathrm{~cm}$ possibly occurred between 1960 and 1975 [Sharp, 1976]. In each case, slip was down to the east along the Imperial fault and down to the west along the Brawley fault. That is, the Mesquite Basin underwent subsidence during each event.

Perhaps the most puzzling and intriguing aspect of deformation in the Mesquite Basin is shown by the offset pattern recorded in the crystalline basement along the Imperial fault. Seismic refraction experiments were conducted by the U.S. Geological Survey in the Imperial Valley during 1978 [Fuis et al., 1984]. Three refraction lines RL-1, RL-2, and RL-3 cross the Imperial fault where shown in Figure 4. (These correspond to Fuis et al. [1984] lines 6NW-1SE-1NW, 1ESE, 1E-2W.) The seismic measurements indicate a $1000 \mathrm{~m}$ basement offset across the Imperial fault at RL-1, a $500 \mathrm{~m}$ offset at RL-2, whereas no basement offset is observed at RL-3. That is, the offset increases to the southeast. Where detectable, the subsurface morphology is down to the east. The basement is defined as rock with $V_{p}=5.6 \mathrm{~km} / \mathrm{sec}$, which approximately corresponds to $5 \mathrm{~km}$ depth. What makes the basement structure so unusual is its opposite arrangement to the deformation displayed at the surface, where vertical fault offsets measured for the 1940 and 1979 earthquakes generally increased to the northwest. In fact, where 
the basement structure is maximum (at $R L-1$ ), the coseismic vertical surface displacements were either small or non-existent. Presumably, this apparent discrepancy between surface and sub-surface structure must illustrate an important tectonic feature.

\section{Age of Faulting}

The correlation between geodetically measured subsidence and the topographic expression shown in Figure 5 strongly suggests this region developed from episodes of seismic activity similar to the 1940 and 1979 earthquakes. In fact, this example clearly illustrates that earthquakes are a fundamental building block of tectonic structures. The $10 \mathrm{~m}$ surface depression, together with the subsidence rate and basement morphology, places constraints on the age of the Mesquite Basin, and correspondingly the northern segment of the Imperial fault.

About $5 \mathrm{~m}$ of seismic and postseismic slip along the Imperial fault north of the border is required to form the $40 \mathrm{~cm}$ subsidence between the earlest and most recent levelings across the Mesquite Basin (1831-1980) [Reilinger, 1984; Reilinger and Larsen, 1986] (additional slip is required to the northest of the basin and along the Brawley fault to produce the detailed deformation pattern). At a plate motion rate of $40 \mathrm{~mm} / \mathrm{yr}$ across the Imperial fault, $5 \mathrm{~m}$ of potential slip will accumulate in 125 years. The equivalent basin subsidence rate is thus about $3 \mathrm{~mm} / \mathrm{yr}$. While depending heavily on the rate of strain accumulation, this analysis is invariant to the earthquake recurrence interval.

At a tectonic subsidence rate of $3 \mathrm{~mm} / \mathrm{yr}$, the $10 \mathrm{~m}$ depression which outlines the Mesquite Basin would form in 3000 years. This suggests that the tectonic framework underlying the basin, namely the northern Imperial and Brawley 
faults, is extremely young compared to the 4 to 5 million year age of the Imperial Valley. However, this estimate does not include sediment influx into the Mesquite Basin. While the measured seismic subsidence is about an order of magnitude larger than typical fill rates in arid regions [Ollier, 1978], the basin is located in one of the largest river deltas in the United States; presumably sediment influx is high. In fact, the average rate of deposit in the central Imperial Valley is about 1 $\mathrm{mm} / \mathrm{yr}$ ( $5 \mathrm{~km}$ over the last 5 million years), only slightly smaller than the rate of tectonic subsidence. Overlying sediments may mask a deeper basin, so 3000 years is an extreme minimum time for basin development.

The lack of an observed basement offset at RL-3 places further constraint on fault age. The geometry and dextral motion of the San Andreas and Imperial faults require extension in the Brawley Seismic Zone. Dip-slip motion along the northern Imperial and Brawley faults helps to fill this requirement. Although geodetic, geologic, and strong-motion data indicate significant vertical displacements along the northern segment of the Imperial fault (north of its intersection with the Brawley fault), apparently insufficient time has elapsed to allow the formation of a detectable basement offset at its northern extent. The lack of offset suggests this region formed relatively recently and is at its earliest stage of tectonic development. Assuming the refraction data can resolve offsets of $250 \mathrm{~m}(1 / 2$ the offset measured at $\mathrm{RL}-2$ ), at a tectonic subsidence rate of $3 \mathrm{~mm} / \mathrm{yr}$ the maximum age for the northern Imperial fault is about 80,000 years; again very young compared to the 4-5 million year age of the Imperial Valley.

Other evidence support a young age for this segment of the Imperial fault. Models of the heat transfer mechanisms, suggest the Salton Sea geothermal field (Figure 4) formed within the last 3500 to 12,000 years [Kasameyer et al., 1980], 
consistent with the 3000 to 80,000 year age range calculated for the Mesquite Basin. If representative of central Imperial Valley tectonics, the geothermal field likely formed contemporaneously with the Brawley Seismic Zone, and correspondingly with the northern Imperial fault. To achieve a balance between thermal constraints and the current composition of the crust, heat flow measurements within the Imperial Valley indicate an average extension rate of $\sim 10^{-14} s^{-1}$ since the formation of the Salton Trough [Lachenbruch et al., 1985]. At this rate, the differential velocity between the Pacific and North American plates requires that extension and faulting must have been distributed over a relatively wide region $(\sim 150 \mathrm{~km})$ during the last $4-5$ million years. Presumably, tectonic and seismic activity, which is presently highly concentrated along the Imperial fault and within the Brawley Seismic Zone, is part of an evolutionary process in which tectonic activity is shifted from one region of the valley to another. The northern Imperial and Brawley faults, Mesquite Basin, and Brawley Seismic Zone may represent the most recent epoch of activity in a rapidly changing fault geometry.

\section{Propagating Rift}

The relationship between seismicity, dip-slip faulting, and basement offset indicate a young age for the northern segment of the Imperial fault. Similarly,

the larger basement offset along the central section of the fault (at RL-1) suggests significant vertical slip along this segment in the past.

We suggest a scenario for the recent history of the Imperial fault and Brawley Seismic Zone, which is consistent with the notion of northwestward propagation of the Gulf of California oceanic rift system. Although rupture along the Imperial fault is predominately strike slip, the large component of normal motion along the 
northern segment of the fault is presumably in response to the en echelon geometry of the San Andreas and Imperial faults. These faults may act as transforms associated with a spreading center beneath the Brawley Seismic Zone [Elders et al., 1972; Johnson, 1979]. If the northern extent of the Imperial fault, as well as the Brawley Seismic Zone were previously further south (perhaps southeast of El Centro), dip slip motion would be expected along this segment of the fault. Eventually, a detectable offset would develop in the crystalline basement. As the spreading center (Brawley Seismic Zone) migrated northwest to its present position, so would the vertical movements during seismic events. Although rupture along the older section of the fault would change to strike slip, a vertical offset would be recorded in the basement. This model can account for the apparent disparity between long-term vertical offsets on the Imperial fault (increasing basement offset to the southeast) and present-day seismic fault slip (maximum dip-slip along the northern segment of the fault).

The rupture pattern for the 1979 earthquake supports this hypothesis (Figure 4). Clearly the northern Imperial and Brawley faults are active components in the stress/strain transfer mechanism between the Imperial and San Andreas faults. Both structures show significant seismic displacements at the surface and at depth. Although displacement along the Rico fault was approximately $10 \mathrm{~cm}$ vertical with no horizontal offset [Sharp et al., 1982; Reilinger and Larsen, 1986], the 1 $\mathrm{km}$ rupture length suggests it is only a minor constituent in the regional tectonics. In fact, the Rico fault may be an older structure reactivated during the 1978 earthquake. The Rico, Brawley, and the north extension of the Imperial fault, each follow a north-south trend and are uniformly spaced at distances of 6 to 7 $\mathrm{km}$. This strong geometrical relationship among the three faults suggest a similar tectonic origin. A schematic illustration of the temporal evolution of this region is 
shown in Figure 6. If the Brawley Seismic Zone was further southeast than at present, the Rico fault may have acted as the Brawley fault does today. Similarly, the Brawley fault would have been the northern splay of the Imperial fault, identical to the present north extension. A prehistoric basin would have developed between the Rico and Brawley faults (forming the observed fault offset), similar to the Mesquite Basin. Presumably, as the Imperial fault lengthened to the northwest, the Rico-Brawley fault system no longer influenced the stress/strain distribution between the northern Imperial and southern San Andreas faults. As a result, a new fault developed (north extension) and the Rico fault died out. Continued migration of the Brawley Seismic Zone may in the future create a new north-south trending structure northwest of the present terminus of the Imperial fault. As the Brawley Seismic Zone shifted to the northwest, so did the southern terminus of the San Andreas fault (Figure 6). The Sand Hills lineament may be the remnant of an older segment of the San Andreas, and except for residual seismic activity, left dormant with the northwest passage of the Brawley Seismic Zone.

It is possible to make a rough estimate for the migration rate of the Imperial fault and Brawley Seismic Zone. Assuming a dip-slip offset rate of $3 \mathrm{~mm} / \mathrm{yr}$ (estimated above), approximately 330,000 years are required to form the $1000 \mathrm{~m}$ basement offset measured along the Imperial fault at RL-1. The 3000 to 80,000 year age for the fault segment $20 \mathrm{~km}$ to the northwest (at RL-3), indicates that the Brawley Seismic Zone has migrated about $20 \mathrm{~km}$ over the last 250,000 to 300,000 years. This yields a migration rate of about $7 \mathrm{~cm} / \mathrm{yr}$. While this rate is only a very crude estimate, it is significant to note that it is quite comparable to the $4.8 \mathrm{~cm} / \mathrm{yr}$ spreading rate in the Gulf of California averaged over the last 3 million years [DeMets et al., 1987]. In fact, the northwesterly migration of the 
Brawley Seismic Zone, and its underlying spreading center, may be directly associated with propagation of the Gulf of California rift system into the North American continent.

\section{Conclusions}

Geodetic, seismic, tectonic, and heat flow data in the Imperial Valley suggest that the northern segment of the Imperial-Brawley fault system is extremely young compared to the 4 to 5 million year age of the Imperial Valley. We find a minimum age of 3000 years based upon the relationship between topography and earthquake induced geodetic displacements, and a maximum age of 80,000 years based upon observed basement offsets across the Imperial fault determined from seismic refraction surveys. A young age is consistent with heat flow data which indicate a distributed and ephemeral pattern of faulting in the Imperial Valley [Lachenbruch et al., 1985].

In addition, we speculate that a disparity along the Imperial fault between the observed seismic vertical displacements (maximum to the north) and the offset recorded in the crystalline basement (maximum to the south) is a direct result of the northwestward propagation of the Imperial fault and Brawley Seismic Zone. A series of evenly spaced north-south surface ruptures and the Sand Hills seismicity lineament are consistent with this hypothesis. A $7 \mathrm{~cm} / \mathrm{yr}$ migration rate, similar to the rate of oceanic spreading in the Gulf of California, is calculated from measured surface displacements and from variations in basement morphology along the Imperial fault. The migration of the Brawley Seismic Zone and Imperial fault may be associated with the propagation of the Gulf of California rift system into the North American continent. 
16

Acknowledgments

We thank the National Geodetic Survey and in particular Emery Balas for providing the leveling data reported here. Comments provided by Kerry Sikh and Hero Kanamori were very helpful and substantially improved the present manuscript, as was a review by Gary Fuss on a much earlier version. This work was supported in part by NASA grant NAG 5-814 and by U.S. Geological Survey contracts 14-08-0001-61679 (MT) and 14-08-0001-61354 (Caltech). Caltech Division of Geological and Planetary Sciences contribution number 487 !

$\uparrow \notin 1354$ 


\section{References}

Allen, C. R., M. Wyss, J. N. Brune, A. Grantz, and R. E. Wallace, Displacements on the Imperial, Superstition Hills, and San Andreas faults triggered by the Borrego Mountain earthquake, U.S. Geol. Surv. Profess. Paper, 787, 84-104, 1972.

Anderson, J. G., and P. Bodin, Earthquake recurrence models and historical seismicity in the Mexicali-Imperial Valley, Bull. Seismol. Soc. Am., 77, 562-578, 1987.

Archuleta, R. J., A faulting model for the 1979 Imperial Valley Earthquake, J. Geophys. Res., 89, 4559-4585, 1984.

Beal, C. H., The earthquake in the Imperial Valley, California, July 22, 1915, Bull. Seismol. Soc. Am., 5, 130-149, 1915.

Brown, L. D., J. E. Oliver, Vertical crustal movements from leveling data and their relations to geologic structure in the eastern United States, Rev. Geophys. Space Phys., 14, 13-35, 1976.

DeMets, C., R. G. Gordon, S. Stein, and D. F. Argus, A revised estimate of Pacific - North America motion and implications for western North America plate boundary zone tectonics, Geophys. Res. Letts., 14, 911-814, 1987.

Doser, D. I., and H. Kanamori, Depth of seismicity in the Imperial Valley region (1977 - 1983) and its relationship to heat flow, crustal structure, and the October 15, 1978, earthquake, J. Geophys. Res., 91, 675-688, 1986.

Elders, W. A., R. W. Rex, T. Meidav, P. T. Robinson, and S. Bieher, Crustal 
spreading in southern California, Science, 178, 15-24, 1972.

Fuis, G. S., W. D. Mooney, J. H. Healy, G. A. McMechan, and W. J. Lutter, A seismic refraction survey of the Imperial Valley region, California, J. Geophys. Res., 89, 1165-1188, 1884.

Hartzell, S. H., and T. H. Heaton, Inversion of strong ground motion and teleseismic waveform data for the fault rupture history of the 1979 Imperial Valley, California, earthquake, Bull. Seis. Soc. Am., 79, 1553-1583, 1883.

Johnson, C. E., CEDAR-An approach to the computer automation of short-period local seismic networks; seismotectonics of the Imperial Valley of southern California, California Institute of Technology, Ph.D. thesis, 343 pp., Pasadena, 1978.

Johnson, C. E., and D. P. Hill, Seismicity of the Imperial Valley, The Imperial Valley, California, earthquake of October 15, 1979, U.S. Geol. Surv. Prof. Pap., 1254, 14-22, 1982.

Johnson, C. E., and L. K. Hutton, Aftershocks and preearthquake seismicity, U.S. Geol. Surv. Prof. Pap., 1254, 59-76, 1882.

Kasameyer, P. W., L. W. Younker, and J. M. Hanson, Age of the Salton Sea geothermal system as inferred from the thermal data, Geol. Soc. Am. Abst., 12, $458,1980$.

Klein, F. W., User's guide to HYPOINVERSE, a program for VAX and PC350 computers to solve for earthquake locations, U.S. Geol. Surv., Open-File Rept. 85-515, 24 p., 1885. 
Lachenbruch, A. H., J. H. Sass, and S. P. Galanis, Jr., Heat flow in southernmost California and the origin of the Salton Trough, J. Geophys. Res., 90, 6709$6736,1885$.

Larsen, S. C., R. E. Reilinger, H. Neugebauer, and W. Strange, GPS measurements of deformation associated with the 1887 Superstition Hills earthquake, Imperial Valley, California: Evidence for conjugate faulting, AGU Chapman conference on GPS measurements for geodynamics, 1988.

Lomnitz, C., F. Mooser, C. R. Allen, J. N. Brune, and W. Thatcher, Seismicity and tectonics of northern Gulf of California region, Mexico: Preliminary results, Geofis. Int., 10, 34-48, 1970.

Magistrale, H., L. Jones, and H. Kanamori, The Superstition Hills, California, earthquakes of 24 November, 1987, Bull. Seismol. Soc. Am., 79 239-251, 1989.

Nicholson, C., L. Seeber, P. Williams, and L. R. Sykes, Seismic evidence for conjugate slip and block rotation within the San Andreas fault system, southern California, Tectonics, 89, 629-648, 1986.

Ollier, C., Tectonies and Landforms, Longman Group Limited, 324 p., 1881.

Pinault, C. T., and T. K. Rockwell, Rates and sense of Holocene faulting on the Elsinore fault: Further constraints on the distribution of dextral shear between the Pacific and North American plates, Geol. Soc. Am. Abstr. Programs, 16, $624,1984$.

Reasenberg, P., and D. Oppenheimer, FPFIT, FPPLOT, FPPAGE: computer programs for calculating and displaying earthquake fault-plane solutions, U.S. Geol. Surv., Open-File Rept. 85-799, 46 p., 1985. 
Reilinger, R. E., Coseismic and postseismic vertical movements associated with the 1940 Imperial Valley, California earthquake, J. Geophys. Res., 89, 45314537, 1884.

Reilinger, R. E., and S. C. Larsen, Vertical crustal deformation associated with the $1878 M_{L}=6.6$ Imperial Valley, California earthquake: Implications for fault behavior, J. Geophys. Res., 91, 14044-14056, 1986.

Sharp, R. V., Surface faulting in Imperial Valley during the Earthquake swarm of January-February, 1975, Bull. Seismol. Soc. Am., 66, 1145-1154, 1976.

Sharp, R. V., Variable rates of late Quaternary strike slip on the San Jacinto fault zone, southern California, J. Geophys. Res., 86, 1754-1762, 1981.

Sharp, R. V., Comparison of 1979 surface faulting with earlier displacements in the Imperial Valley, U.S. Geol. Surv. Prof. Pap., 1254, 213-221, 1982.

Sharp, R. V., J. J. Lienkaemper, M. G. Bonilla, D. B. Burke, B. F. Fox, D. G. Herd, D. M. Miller, D. M. Morton, D. J. Ponti, M. J. Rymer, J. C. Tinsley, J. C. Yount, J. E. Kahle, E. W. Hart, and K. E. Sieh, Surface faulting in the central Imperial Valley, U.S. Geol. Surv. Prof. Pap., 1254, 119-143, 1982.

Snay, R. A., M. W. Cline, and E. L. Timmerman, Horizontal crustal deformation models for California from historical geodetic data, Royal Society of New Zealand, Bulletin 24, 131-140, 1986.

Snay, R. A. and A. R. Drew, Supplementing geodetic data with prior information for crustal deformation in the Imperial Valley, California, Technical Report Series, Geodetic Institute, University of Stuttgart, 1988. 
Sykes, L. R., and S. P. Nishenko, Probabilities of occurrence of large plate rupturing earthquakes for the San Andreas, San Jacinto, and Imperial faults, California, 1983-2003, J. Geophys. Res., 89, 5905-5927, 1984.

Trifunac, M. D., and J. N. Brune, Complexity of energy release during the Imperial Valley, California, earthquake of 1940, Bull. Seismol. Soc. Am., 60, 137-160, 1970.

Weldon, R., and E. Humphreys, A kinematic model of southern California, Tectonics, 5, 33-48, 1986.

Williams, P. L., and H. W. Magistrale, Slip along the Superstition Hills fault associated with the 24 November 1987 Superstition Hills, California, Earthquake, Bull. Seismol. Soc. Am., 79, 390-410, 1989. 


\section{Figure Captions}

Figure 1 - The Salton Trough (hatch pattern) is a transition zone between crustal spreading in the Gulf of California and right-lateral transform motion along the San Andreas fault. The Imperial Valley is that portion of the Salton Trough north of the U.S. - Mexico border and south of the Salton Sea. Abbreviations are S.F., San Francisco; L.A., Los Angeles. Map modified from Lachenbruch et al. [1985].

Figure 2 - The Imperial Valley and important faults. The Mesquite Basin is a subaerial topographic depression of about 10 meters between the Imperial and Brawley faults.

Figure 3 - Seismicity in the Imperial Valley between 1932 and 1989 (Caltech/USGS Catalog). Major events include the 1840 Imperial Valley ( $M_{S}$ $=7.1), 1968$ Borrego Mountain $\left(M_{L}=6.5\right), 1979$ Imperial Valley $\left(M_{S}=\right.$ 6.6), and the 1987 Superstition Hills $\left(M_{S}=6.6, M_{S}=6.2\right)$ earthquakes. The Brawley Seismic Zone is the active region between the northern reach of the Imperial fault and the southern extent of the San Andreas. The Sand Hills Seismic Lineament is shown by the shaded strip outlining earthquakes trending southeast from the southern end of the San Andreas fault. Shown in the inset are aftershocks of the 1979 earthquake which have been relocated following the methods outlined in Doser and Kanamori [1986]. The dashed lines represent orthogonal faults used to satisfy the observed vertical deformation from the 1979 event [Reilinger and Larsen, 1986]. Focal mechanisms (lower hemisphere, equal area projections [Reasenberg and Oppenheimer, 1985]) for events defining a northwest trend indicate right-lateral strike slip 
motion.

Figure 4 - Map of the Imperial Valley and important tectonic features. Abbreviations are RF, Rico Fault; BF, Brawley Fault; NE, North Extension. The shaded pattern along each fault indicates the surface rupture from the $197 \theta$ earthquake. The Brawley Seismic Zone (hatched) is the region of high seismicity extending northwest from the northern reach of the Imperial fault. The Salton Sea Geothermal Field is the shaded pattern along the southern section of the Salton Sea. Refraction surveys [Fuis et al., 1984] cross the Imperial fault at RL-1, RL-2, RL-3. The leveling route is shown by the series of dots from the central Imperial Valley to the eastern border of the Salton Sea (each dot representing a benchmark).

Figure 5 - Shown in a) is the elevation (dashed line) along the releveling route between EI Centro and the Salton Sea. The adjusted topography (solid line) is the elevation with the northward tilt of -0.0011 radians removed. The 10 meter depression between 9 and $22 \mathrm{~km}$ is the surfacial expression of the Mesquite Basin. Shown in b) are the elevation changes along the leveling route from 1931 to 1941,1941 to 1974 , and 1978 to 1980 . Note the strong correlation between deformation and the surface expression of the Mesquite Basin.

Figure 6 - Schematic diagram of past and present fault configurations in the Imperial Valley illustrating the hypothesized northwesterly migration of the Brawley Seismic Zone. In this model the Sand Hills Seismicity Lineament is the extension of the San Andreas, left dormant after the passage of the Brawley Seismic Zone. 


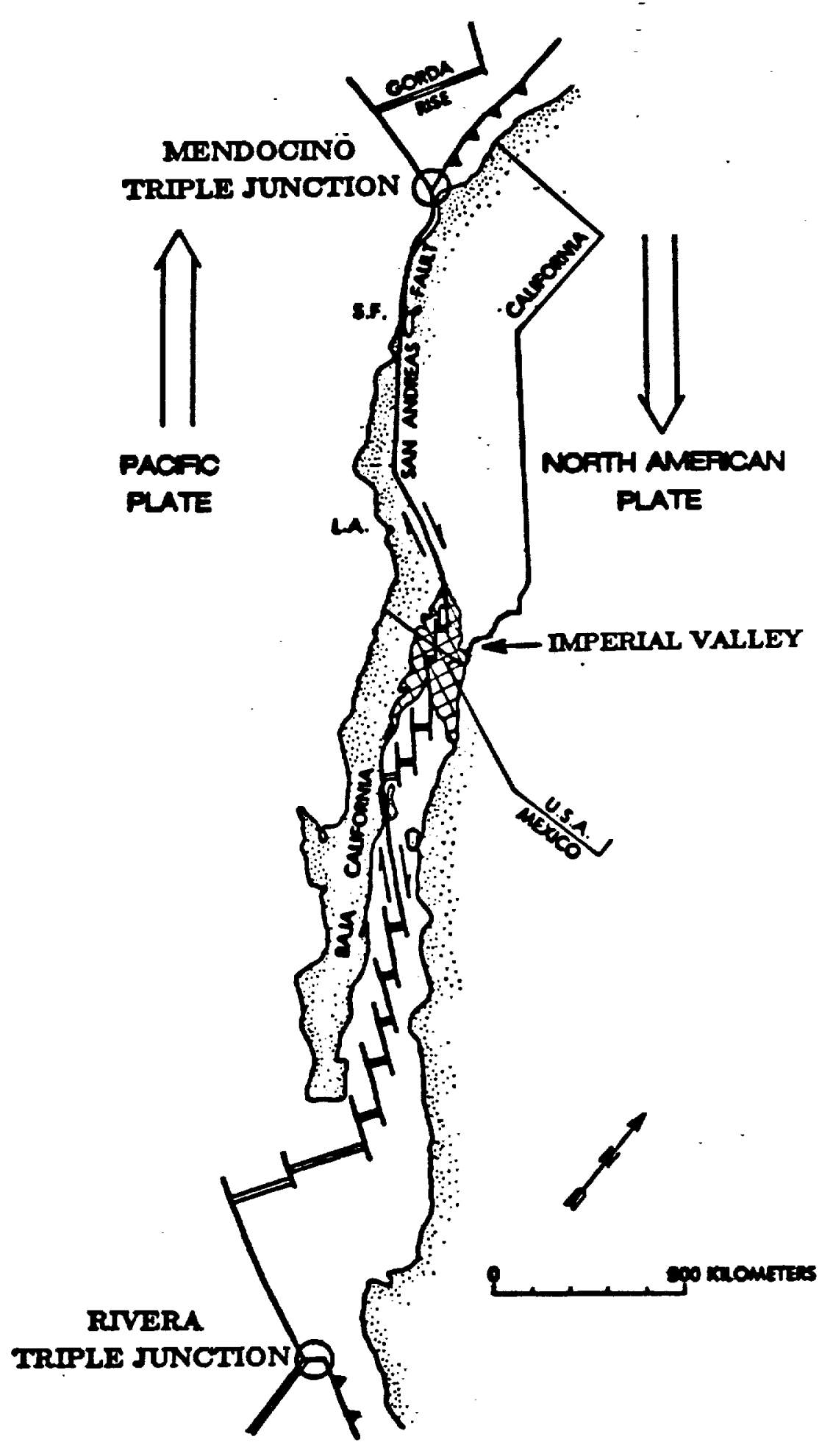




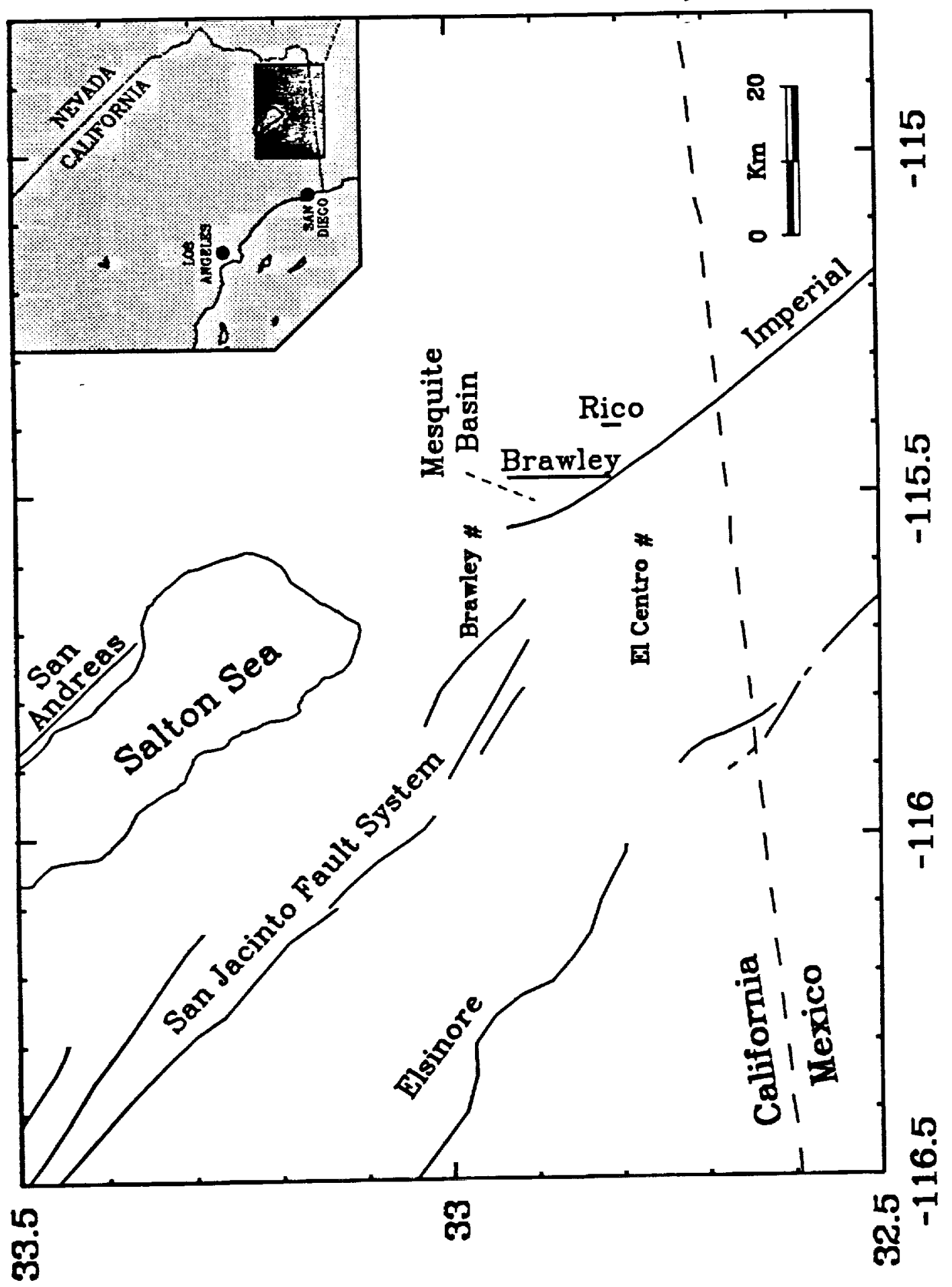

(2) 


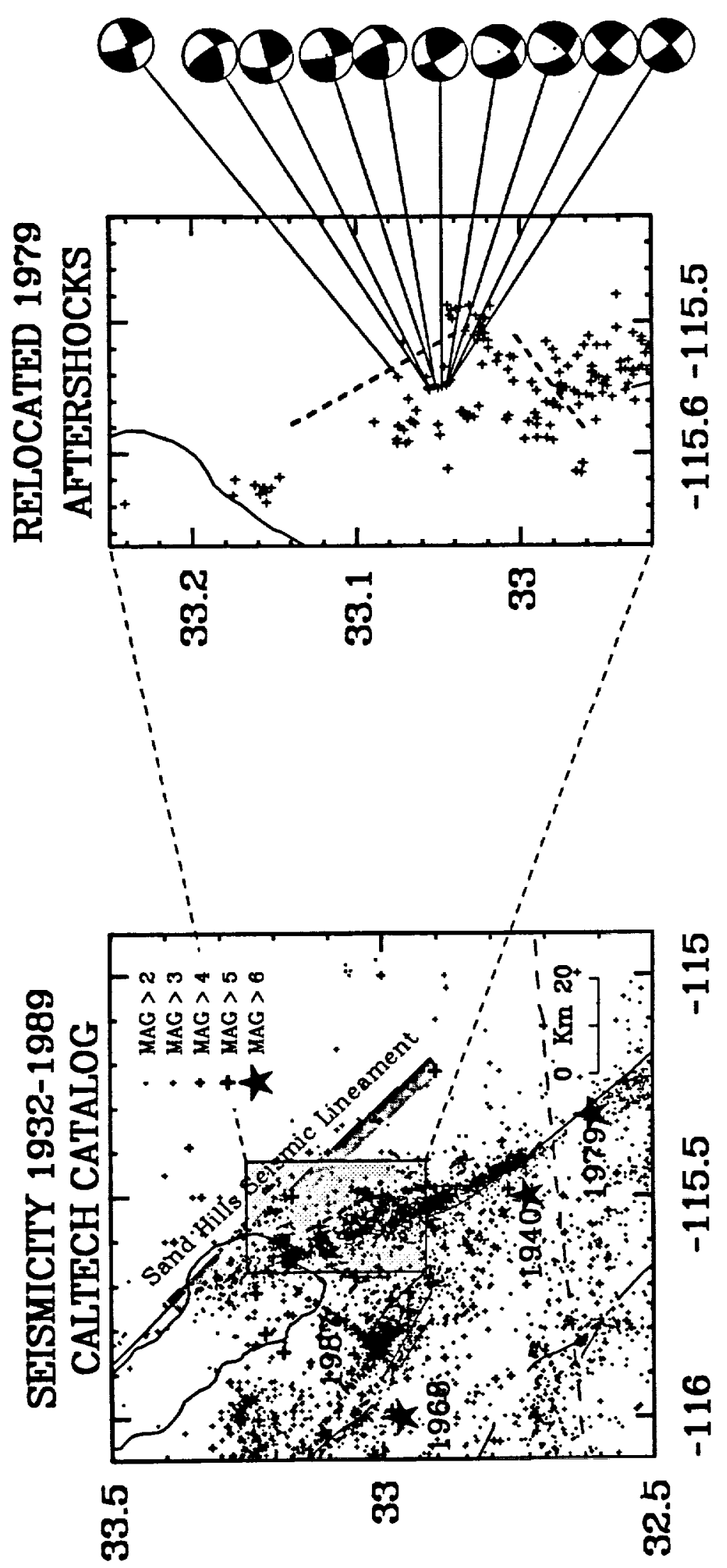

(3) 


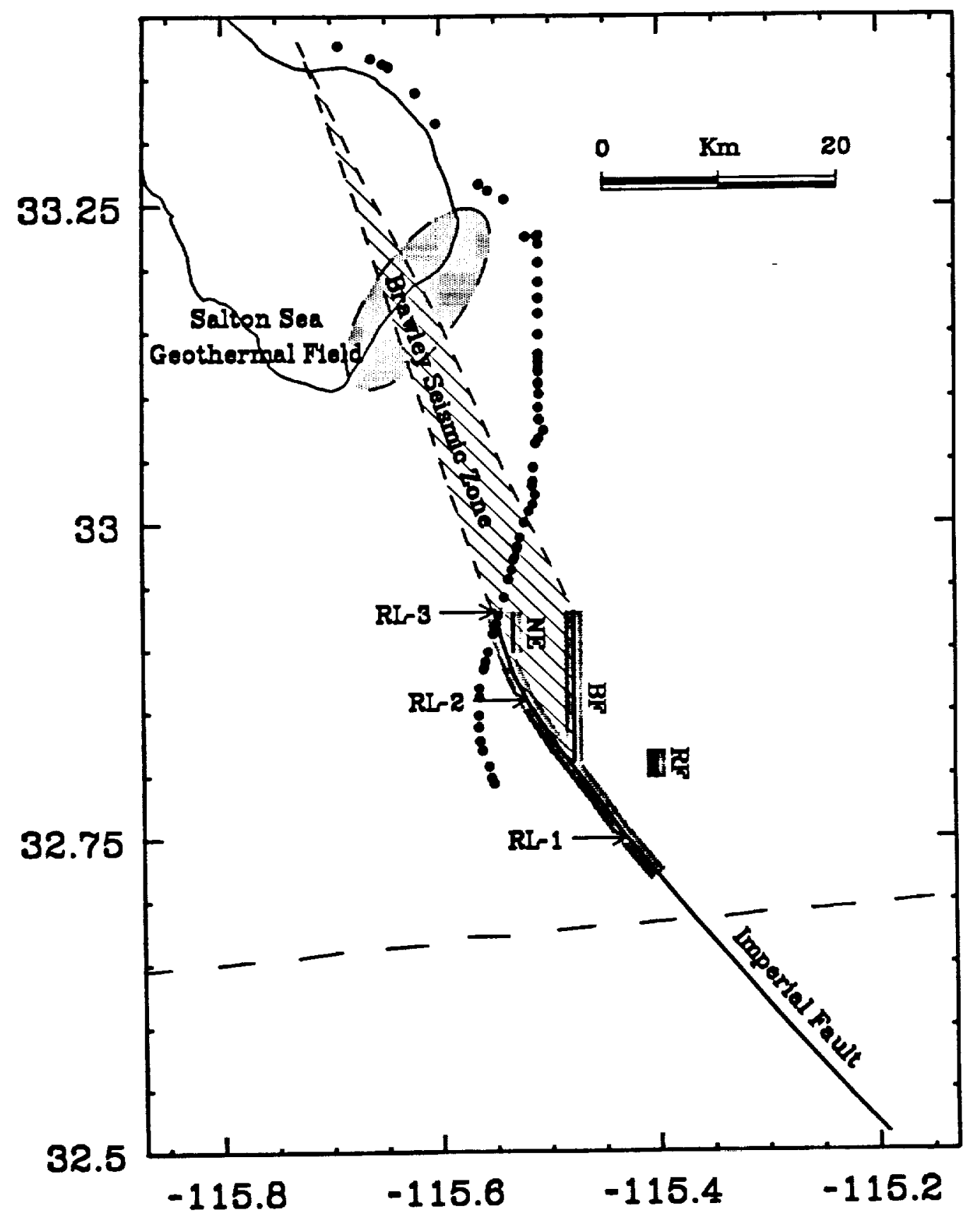



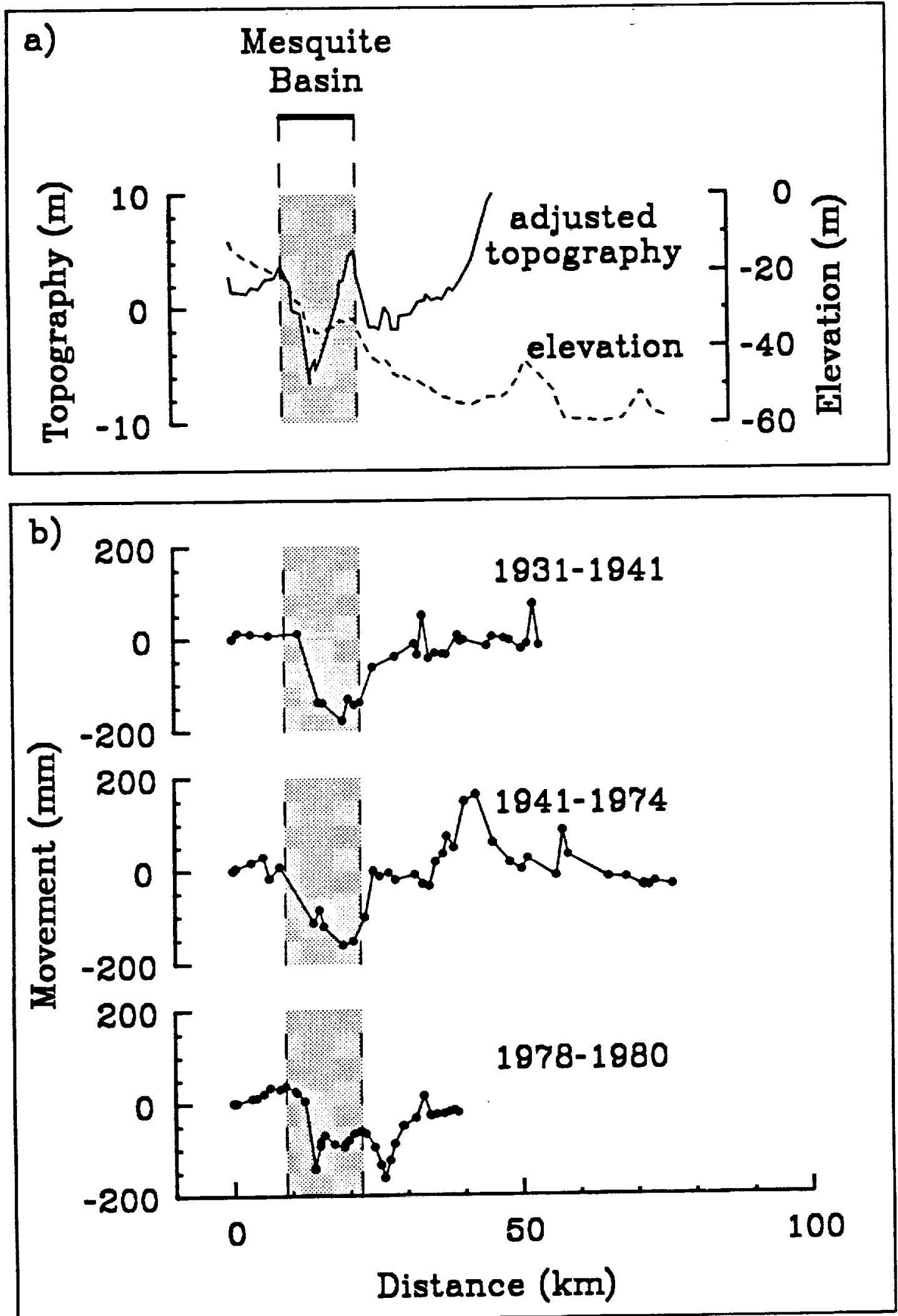

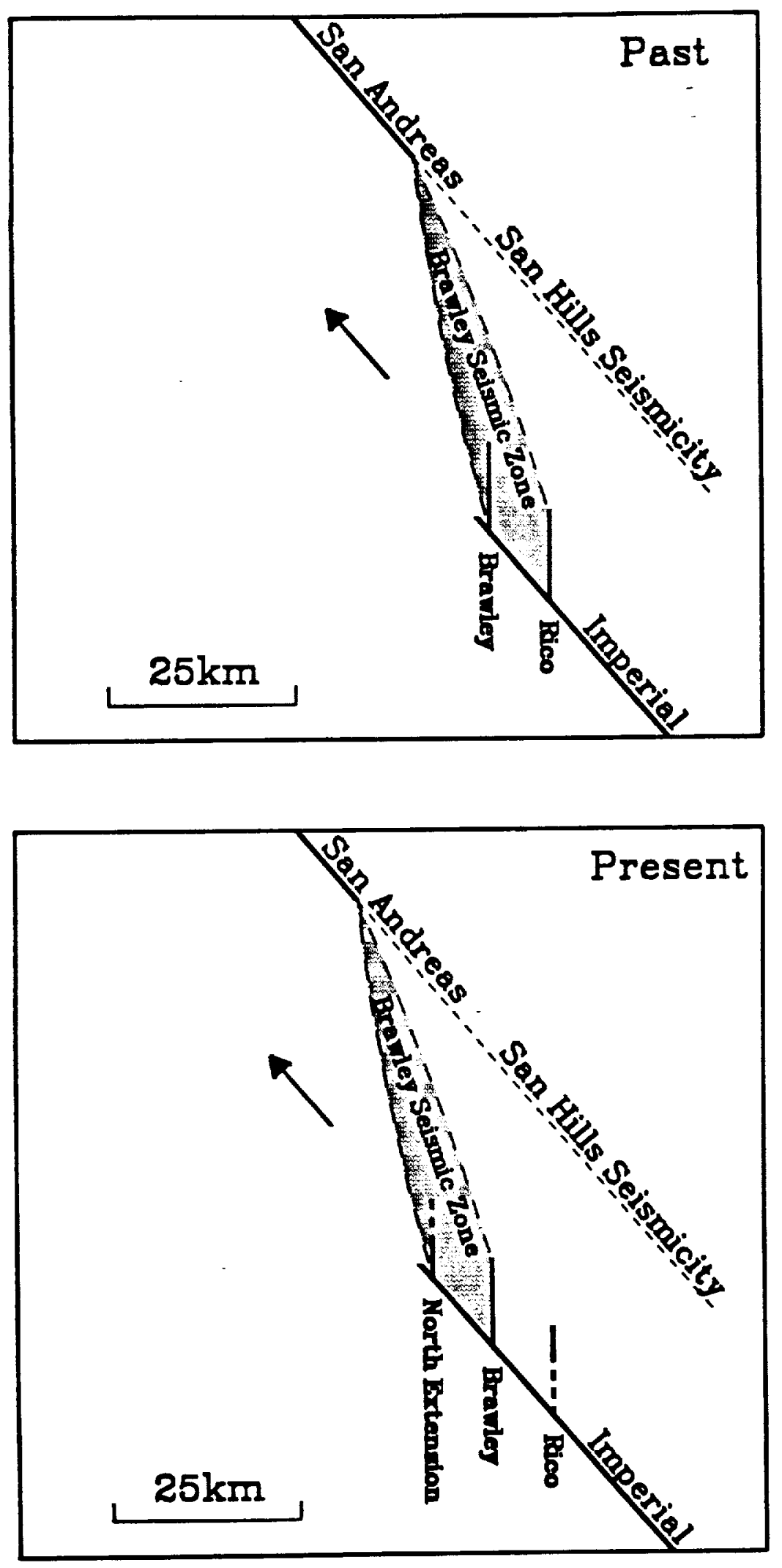

(6) 